\title{
THE LEGAL ORDER AS A FACTOR OF INVESTMENT ATTRACTIVENESS OF UKRAINE FOR DOMESTIC AND FOREIGN ENTREPRENEURS
}

\section{Kryzhanovskii A. F.}

\section{INTRODUCTION}

Legal order, as a phenomenon "integrally" reflecting the legal climate in all spheres of society, including economy, business, investment, greatly affects the investment attractiveness of the country. In order to improve the investment attractiveness of their own country, the authorities should take into account that business is extremely sensitive to changes in security and guarantees, stability and reliability of its operating conditions in investment country. The author analyzes various aspects of the Ukraine Government policy concerning strengthening of the legal order in the economic sphere, regulatory activity, financial guarantees and personal security as factors of our country's investment attractiveness in the current conditions and in the future.

\section{The legal order as the context of being human and society}

Every person, if asked, whether they "feel" the legal order in their environment is likely to answer affirmative that question. Indeed, a person feels that the events around indicate either relative safety, predictability, orderliness of social life, or vice versa, threatened by some danger from the surrounding world, which is dominated by disorder, unpredictability, and therefore that it can protect. Determining the level (degree, quality) of orderliness of others around the world is an immanent need, because only by "satisfying" it we can develop a strategy for our further life. To a large extent, a person's constantly tendency to "monitor" the state of safety of the surrounding world remains not only as a "rudiment" of natural experience. Defining a person environment as hostile, favorable, means for a person the opportunity to "save" physical and spiritual forces, to use them in other directions.

The legal order is the phenomenon that marks the "civilization" of the society of human need for security as a natural being in a legal form, which, in fact, is caused by the existence of a social type of human life.

Therefore, the claim that there is a legal order, that it is a reality from the world of our existence, is not in doubt. Another matter is the question of what kind of "appearance", the external manifestation has a legal order, according to which manifestations we can determine its absence or presence, and those 
or other gradations of its partial or sufficient "presence" in public life. Answering these questions, theory of law can not do without addressing the specifics of legal existence.

Law and legal phenomena are a special form of social existence and a specific reality, the unique nature of which acquires specific forms of expression, and therefore - the perception of person.

Unlike the economy, which exists in the form of human activity and social relations, in the process of which human beings are created, or the state, which, in turn, functions in the form of powerful political-territorial institutions, the social "existence" of law is quite peculiar. Law is not one of the objects that can be directly observed, perceived as a specific object. $\mathrm{He}$ has no clearly defined place in the surrounding physical space. All existing attempts to build his philosophical-theoretical model are forced to rely on the existing spiritual and practical experience accumulated over many generations. It gives him the opportunity to build such models. But the basis for the creation of these models must be completely different, independent of the criteria of sensory perception ${ }^{1}$.

With regard to understanding the legal order in modern conditions, this approach is of particular importance, because in the scientific literature devoted to its study, the perception of law and order as a phenomenon of ideal nature dominates mainly as a theoretical construction.

Law and legal phenomena exist in society (in comparison with other institutions of social life) in various "hypostases": in the "form" of officially recognized, formally defined norms, models and standards of behavior (legal norms), in the form of legal consciousness and in the form of acts legal behavior and legal relations. Therefore, it is difficult to agree with the statement that the right exclusively relates to the spiritual life of society ${ }^{2}$. Law also includes a component of "objectivity", and not only one that is related to its "positive" manifestation. Law is a way (form) of material and substantive activity of society, which ensures its self-preservation and development. By the way, it was precisely this combination of spiritual and substantive in legal reality that pointed out B.O. Kostyakovsky, who compared it with the reality of works of sculpture and painting on the one hand, and works of literature and music - on the other, recognizing the law a little closer to the reality of the first kind cultural benefits than the other ${ }^{3}$. With this view of an outstanding domestic jurist echoes and observations of another well-known

\footnotetext{
${ }^{1}$ Бачинин В.А. Философия права и преступления. Харьков: Фолио, 1999. С. 13.

2 Алексеев С. С. Право: азбука - теория - философия: Опыт комплексного исследования. М.: "Статут”, 1999. 226.

${ }^{3}$ Кистяковский Б. А. Социальные науки и право. Очерки по методологии социальных наук и общей теории права. М., 1916. С. 336.
} 
researcher of the problems of philosophy and theory of law. From the point of view of the genesis of the legal nature of man (and at the same time the assertion of the principles of law and law and order in the life of entire nations), the realization of the fact that in the abstractions of law by external conditionality it is the most important and essential in the life of the individual and the whole society plays a decisive role - about freedom, justice, equality, that legal "conventions" are in fact absolutely necessary conditions for a decent human life of everybody and everyone ${ }^{4}$. Therefore, the right, while remaining a phenomenon from the social spiritual world, has at the same time - though not in general, but still in some way has - merged with its external form and hence - a visible and existing character.

For further development of legal order research, development of scientific provisions for its providing in modern conditions, it is important to analyze all forms of manifestation of the legal order in public life, which combine all aspects of its existence as a coherent institutional socio-legal phenomenon, which manifests itself as a legal reality independent element.

The legal order is an integral part, an element of legal reality, which is formed in society as a result of the existence and functioning of law and legal phenomena, social and legal consequences and processes generated by law.

As a phenomenon of legal reality, the legal order is characterized by features inherent in it as a whole internally structured phenomenon.

Like law as a whole, the legal order is a universally recognized fact and an integral part of the official, public and private legal life existing in society, which manifests itself daily in the multifarious circumstances of individuals life, communities and their associations. The legal order, as well as the law as a whole, by the words of I.O. Pokrovsky, is a certain sociopsychological force that regulates people's behavior; it is a certain state of social consciousness and social will, which contains a psychic compulsion to some behavior. As a phenomenon of social psychology, the legal order is thus an undoubted reality, a fact of empirical reality, part of the "world of being" 5

Like law as a whole, the legal order is some extent characterized by such property as coercion: to ensure law and order, to protect it from unlawful encroachment by means of coercive nature.

Like law, the legal order is characterized by a well-established internal structure - its own structure (legal relations, implementation of law, lawful behavior, irregular legal practices, offenses, etc.).

${ }^{4}$ Нерсесянц В. С. Философия права. Учебник для вузов. М.: Издательская группа ИНФРА - М - НОРМА, 1997. С. 42.

${ }^{5}$ Покровский И.А. Основные проблемы гражданского права. М.: Статут. 1998. С. 60. 
Like the law as a whole, the legal order is characterized by objective laws of "existence and development" $"$.

On the other hand, the legal order appears to be a rather peculiar legal reality. The rule of law does not have a documentary likeness characteristic of the positive law components. The substantive, substantive nature of the rule of law comes from the valid actions of social subjects (law-making and implementation of law, enforcement, interpretation of legal orders, etc.), which form a coherent, established legal reality - a certain state of legal ordering of social life. Legal order in this sense emerges as an important sphere of being a society, namely a legal being that interacts with the whole system of social relations and ties, and exists as a certain form of "being of legal matter"7.

The question of how legal is "real" is not only scholastic, scientific. Specific people in their lives encounter specific legal phenomena - get acquainted with the content of the laws, learn about certain facts of a valid character (for example, that a famous Russian businessman bought one of the leading English football clubs "Chelsea", or that the combine Kryvorizhstal sold the state to the foreign owner, or the election of the President of Ukraine), the offenses committed in the society, or the actions of law enforcement agencies, justice, etc. In the course of their own legal practice, people are confronted with the legal behavior of others - managers, officials, colleagues, clients, law enforcement officials, ordinary citizens, offenders. As a result, in the mind of each person a certain relation to the surrounding legal life is formed. It encompasses both the assessment of current legislation, the level of legal protection of a person in this society, and the ability to exercise their legal rights and interests. The perception of a person related to the legal order is largely subjective, depends on the level of legal consciousness of the person, the development of his spiritual and legal world, legal experience, etc.

Law and order is that part of legal reality that cannot be fully understood in its entirety by the consciousness of an individual. The individual perceives certain facts, situations that are fragments of the whole legal order (the socalled "objective" legal order). The whole picture of the public order is reflected in the public consciousness. Features of human consciousness are manifested in the fact that on the basis of fragmentary perception of the surrounding world (a limited number of facts, circumstances and situations, a certain circle of social relations), a person constructs a holistic, generalizing

\footnotetext{
6 Алексеев С. С. Право: азбука - теория - философия: Опыт комплексного исследования. М.: “Статут”, 1999. С. 230.

7 Дражина И. В., Пономаренко Е. В. Правовое освоение действительности в системе юридических категорий. Тюмень, 1995.
} 
picture of the world, its certain image (the mechanism of this process may resemble the reconstruction of the reconstruction found by archaeologists of an individual element of the animal) The "configuration" of an image of the legal order, its substantive content depends on many factors, objective and subjective. But its disadvantages, some deformations of the perception of the legal order, to some extent, are inherent in even the scientific forms of comprehension of the surrounding world.

Thus, the real facts of the legal life of many people, that is, society, are somehow combined into a "general picture", a coherent system of legal existence of a society that constitutes a certain legal system, a social and legal climate of coexistence of people, which is reflected in the public consciousness. Specific people and society as a whole feel the influence of this system on their lives in the way they solve the problems of their legal nature (at work, in relations with the authorities, when applying to law enforcement or justice authorities). For law-abiding citizens, it is also likely to be the target of the offense, and for the offender to be able to avoid being held accountable for such acts.

The reality of the legal order is manifested in the fact that it exists as separate from other phenomena of the material world, along with these phenomena, and in unity with the surrounding world as a whole, there is a legal reality. Like some other legal phenomena that have the character of externally objective entities - institutions, that is, "educated" and "objectified" social phenomena, which as a result of alienation have acquired their own existence and, unlike the individual and social consciousness as such, are embodied in externally delineated, structurally determined, solid and established forms of existence and functioning ${ }^{8}$, law and order as a fixed form of social and legal existence is able to act as a firm and solid foundation or criterion for human behavior.

The legal order has some relation to the "geometry", geography and temporal characteristics of social and legal being, it is a "physical" space in its specific manifestation, one of the dimensions of the space of human being, along with political, economic, religious and other.

\section{Legal climate and investment image of Ukraine}

A specific feature of the legal order in the sphere of investment activity is its formation as the domestic law of the country and international investment law. The situation in the country can either contribute to or oppose the establishment of a favourable legal order (legal framework).

\footnotetext{
8 Алексеев С. С. Право: азбука - теория - философия: Опыт комплексного исследования. М.: “Статут”, 1999. С. 228.
} 
However, experts on international investment law emphasize that in the ratio of national and international investment law, they operate as separate, but mutually agreed interacting legal systems ${ }^{9}$. In accordance with the Vienna Convention on the law of treaties, 1968 years (art. 27), the State may not invoke its internal law, including the Constitution, as a justification for failure to comply with their international obligations ${ }^{10}$.

Sources of international investment law are, inter alia, bilateral international agreement decisions on promotion and protection of investments, for the avoidance of double taxation, trade agreements, agreements on the settlement of economic contracts and industrial with cooperation, as well as multilateral agreements. Among the most important documents of this kind include the Washington Convention on the procedure for settling arguments between the State and the face of another State of the year $1965^{11}$, the Seoul Convention establishing the multilateral investment guarantee agency (MIGA) of the year $1985^{12}$, the agreement on trade-related aspects of foreign investment (TRIM) in force in the $\mathrm{WTO}^{13}$ system, etc.

In accordance with the Seoul convention, the Interstate organization conducting insurance investment risks - the multilateral agency on guarantee investment was established. The investors, who concluded guarantee contracts with the Agency, provided the economic rationale for investment may obtain from the Agency of monetary compensation at insurance event occurrence. After the compensation payment, the Agency has the right to claim these funds from the state-recipient.

In Ukraine there is a block of special normative legal acts, regulating relations in the country. They are the laws of Ukraine "On investment activity"14, "On the regime of foreign investments"15, "On protection of foreign investments" 16 , "On Elimination of discrimination in the taxation of

9 Фархутдинов И. З. Международное инвестиционное право и процесс. Изд-во “Проспект". 2010. С. 82.

10 Действующее международное право. Документы в 2-х томах. Т. 1. Составители Ю. М. Колосов, Э. С. Кривчикова. М.: Междун. отношения. 2002. С. 352.

11 Конвенція про порядок вирішення інвестиційних спорів між державами та іноземними особами. URL: https://zakon.rada.gov.ua/laws/show/995_060

${ }^{12}$ Сеульська конвенція 1985p. про заснування багатостороннього агентства 3 гарантій інвестицій. URL: https://zakon.rada.gov.ua/laws/show/995_268.

${ }^{13}$ Угода про пов'язані з торгівлею інвестиційні заходи. URL: https://zakon5.rada.gov.ua/ laws/show/981_009/

14 Закон України “Про інвестиційну діяльність”. Відомості Верховної Ради Украӥни (ВВP). 1991, N 47, ст. 646.

15 Закон України "Про режим іноземного інвестування". Відомості Верховної Ради Украӥни (ВВР). 1996. № 19. Ст. 80.

16 Закон України "Про захист іноземних інвестицій на Україні". Відомості Верховної Ради Украӥни (ВВР). 1991, N 46, ст. 616. 
business entities created using the property and assets of national origin" ${ }^{17}$ as well as the Economic Code of Ukraine ${ }^{18}$. Ukraine ratified the Convention on the procedure for settlement of investment disputes between States and foreign citizens (March 16, 2000) ${ }^{19}$.

These are fundamental legal acts, which are designed to form the basis of the legal order in the field of investment activity, and, therefore, are able to influence the investment climate and investment attractiveness of our country in the eyes of foreign investors. Among the factors that also have a positive effect on the state of the legal order; legal guarantees for foreign investors in Ukraine take an important place.

Among the most important guarantees that Ukrainian legislation establishes with respect to foreign investors are the guarantee of stability of the conditions for carrying out investment activities, respect for the rights and legitimate interests of its subjects. State bodies and their officials do not have the right to interfere in the activities of subjects of investment activities, except when such interference is allowed by current legislation and is carried out within the competence of these bodies and officials ${ }^{20}$. Article 397 of the Economic Code of Ukraine, among the most important guarantees, also provides for compensation and compensation for losses to foreign investors ${ }^{21}$. Compensation and reimbursement to foreign investors of losses caused to them as a result of actions, inactivity, or improper fulfillment by the state authorities of Ukraine or their officials of obligations regarding a foreign investor or an enterprise with foreign investments includes not only direct damage, but also lost profits, as well as moral damage (damage business reputation).

At the same time, the complex of legal guarantees stipulated by the legislation of Ukraine regarding foreign investments implies that the Ukrainian legislation imposes certain requirements on the actions of a foreign investor.

First of all, these are the requirements of doing business in Ukraine legally, in full compliance with Ukrainian legislation. In 2016, in order to

17 Закон України “Про усунення дискримінації в оподаткуванні суб'єктів господарювання, створених з використанням майна та коштів вітчизняного походження". Відомості Верховної Ради Украӥни (ВВР). 2000. № 12. Ст. 97.

${ }_{18}$ Господарський Кодекс України. Відомості Верховної Ради Украӥни (ВВР). 2003. № 18. № 19-20. № 21-22. Ст. 144.

19 Конвенція про порядок вирішення інвестиційних спорів між державами та іноземними особами. URL: https://zakon.rada.gov.ua/laws/show/995_060

20 Закон України Про інвестиційну діяльність. URL: https://zakon.rada.gov.ua/ laws/show/1560-12.

${ }^{21}$ Господарський Кодекс України. Відомості Верховної Ради України (ВВР). 2003. № 18. № 19-20. № 21-22. Ст. 144. 
maximally simplify the procedure for attracting investments by introducing the declarative principle of their state accounting, Article 395 of the Economic Code was abolished, which required the registration of foreign investments by local state administrations, as well as the relevant provisions of other legal acts. The elimination of administrative control (and the corruption pressure on foreign investors) removed unjustified obstacles to business.

Nevertheless, the fact of foreign investments is recorded in the statutory documents of economic entities and is entered into the Unified State Register of legal and natural persons-entrepreneurs. The subsequent operation of the business in accordance with the requirements of the law (for example, compliance with labor laws in relation to employees, payment of taxes, etc.) is also assumed.

The question of which institutions of justice are really designed to protect a foreign investor is also very important. Ukraine supports the jurisdiction of foreign institutions operating in this area. Thus, investment disputes may be considered by arbitration provided for by the Arbitration Rules of the United Nations Commission on International Trade Law. Investors are entitled to apply for the protection of their rights to the International Center for the Regulation of Investment Disputes, established in accordance with the Convention on the procedure for resolving investment disputes between states and foreign citizens ${ }^{22}$.

Such cases can also be considered in the European Court of Human Rights, and in the state courts of Ukraine.

It should be noted the close relationship between the legal order, the investment climate, and the investment attractiveness of the country. The categories "investment attractiveness" and "investment climate" are interpreted differently in economic research. Some researchers identify them; others see significant differences between them ${ }^{23}$. Without going into details of expert discussions, it should be noted that each of these categories has its own meaning, although in a certain part they intersect and complement each other. At the same time, investment attractiveness is a peculiar result of the investment climate and legal order.

As in any case of making decisions on the allocation of capital, the entrepreneur is guided by two main considerations: 1) the investment image of the target country and 2) the objective characteristics of the investment climate in it. Each of these phenomena has its own nature, its own mode of

22Конвенція про порядок вирішення інвестиційних спорів між державами та іноземними особами. URL: https://zakon.rada.gov.ua/laws/show/995_060

${ }^{23}$ Курпаяниди К.И. Актуальные вопросы оценки инвестиционной привлекательности и факторы активизации инвестиционных потоков. Экономика, предпринимательство $u$ право. 2011. № 9. С. 11-18. 
existence, but they are closely linked, in one way or another, correlating each other.

The investment image is formed by business entities as an informal conceptual characteristic of the business environment in the country, which, above all, characterize economic efficiency in the most general characteristics of the possible financial effect from an investment project. The investment image of the country is shaped primarily by informal channels, business communications, the Internet environment, an independent press, and so on. What is not less important is the perception by the subject of the decision to invest in a given country of the decisive relationship between the risks and the financial efficiency of this project. And here begins the peculiarities of individual perception by a potential investor of many factors that are important in order to induce his decision in favor of this project. The investment image has the form of a kind of "matryoshka" in which the investment image of the country is consistently located, and further in it is the investment image of the region, city (industry), and particular enterprise. A special component of this image is information disseminated through unofficial channels about the political context and legal security of a business in Ukraine. If the sum of positive characteristics of a particular subject of decision making outweighs the conditional risks, this project can take place. In the case of the analyzed issues of attracting foreign investment in Ukraine, given the mentality and peculiarities of foreign psychology, it is the negative image of Ukraine in recent years that has been the main factor deterring foreign investors from coming to Ukraine. It should be recognized that in 2010-2013, by "joint actions" of the authorities and criminals, the investment image of Ukraine suffered significant image damage, which is gradually but steadily being overcome in our time. The main trend in this is the promotion of our country towards the introduction of European standards and business guarantees. This is not to say that this promotion is easy and smooth. But there is a feeling that the political will of the current and potential power is committed (more precisely, doomed) to follow this vector. And this is probably our best "informal" message to foreign entrepreneurs who are closely eyeing Ukraine.

The objective characteristic of the investment climate in the economic doctrine is called "investment attractiveness". In the most general form, investment attractiveness is a set of characteristics that allow a potential investor to assess how much an investment object (enterprise, industry, region, country) is more attractive than others for the investment of funds required for this investment project.

Among the factors that businessmen undoubtedly weigh, considering Ukraine as a country of location, legal (legal) conditions and guarantees of business functioning in our country are important. 
Regarding the state and trends that characterize the legal sphere, "responsible" for the investment business in Ukraine, there is a wide range of opinions - from cardinally negative to just as radically positive on the part of narrowly politically motivated characteristics. I will not argue that "the truth is, as always, in the middle" - we will try to analyze the facts.

The Law of Ukraine "On Amendments to Certain Legislative Acts of Ukraine regarding the simplification of business conditions (deregulation) and attracting investments by issuers of securities" ${ }^{24}$, adopted in 2018 , is intended to drastically improve the situation in limiting negative bureaucratic influence on business.

Another effective factor in protecting business in Ukraine should be the institution of a business ombudsman, a draft law introducing which is under consideration by the Ukrainian parliament.

An important component of the approval of European business standards in Ukraine is the policy of improving the financial sector and reforming the banking system. Since 2015, measures have been taken to remove insolvent banks from the market to clean up the banking system from institutions that had systemic risks, which should lead to a return of confidence in the national banking system, and as a result, to resume the proper level of lending, which is more necessary than ever for accelerated development business.

For businessmen information on the gradual improvement of the conditions for doing business in the field of agricultural production in Ukraine may be interesting. The most common form of agribusiness in Ukraine, acceptable to foreign investors, are business partnerships, which may be national, foreign, or with foreign investment.

One of the landmark legal tools that have emerged in the arsenal of business and investment protection in recent years in Ukraine is a production claim introduced by the Verkhovna Rada of Ukraine and signed by the President of Ukraine - the Law of Ukraine "On Amendments to Some Legislative Acts of Ukraine Concerning the Protection of Investors' Rights" No. 289 - VIII of April 7, 2015, which entered into force on May 1, $2015^{25}$. A production claim is a claim for damages filed by the participants of the economic company in order to declare the actions of the officials of this company illegal, which is the formal basis for compensation for the damage caused. The plaintiff in such cases is a business entity, in whose interests a claim is filed for damages caused to this company by the actions (inaction) of its official.

24 Закон України "Про внесення змін до деяких законодавчих актів України щодо спрощення ведення бізнесу та залучення інвестицій емітентами цінних паперів". Відомості Верховної Ради (ВВР). 2018. № 6-7. Ст. 38.

${ }^{25}$ Відомості Верховної Ради (ВВР). 2015. № 25. Ст. 188. 
The right to submit a claim to the court on behalf of the economic company, as well as a statement on the implementation of the representative of the claimant was granted to the participant (shareholder) of this company, who jointly owns 10 or more percent of the authorized capital (ordinary shares) of the company. These persons will have the status of a representative of the relevant company.

Such a representative can carry out the representation of the company personally (if it is an individual), through its bodies (if it is a legal entity), government bodies, authorities of the Autonomous Republic of Crimea, local governments (if it is a state, Autonomous Republic of Crimea, territorial community), through its other representatives. At the same time, a participant (shareholder), who collectively owns 10 or more percent of the authorized capital (ordinary shares) of a company, may carry out the company's representation through one of the participants (shareholders), or jointly authorize another person, as provided for by the new, 8 article 28 part Economic Procedural Code of Ukraine ${ }^{26}$.

As it is known, one of the most important barriers that recently kept Western investors from coming to Ukraine was the lack of real independence of courts from the political and administrative influence of the legislative and executive authorities, their corruption, as well as the unacceptable corruption of the police, customs, fiscal authorities, the licensing system and others.

Among the measures that, in the opinion of the authorities in Ukraine, should resolutely contribute to the improvement of the judicial system are the adoption of the Law of Ukraine of June 2, 2016 № 1402-VIII "On the judicial system and the status of judges" 27 . Fundamental changes in the judicial system and the legal status of judges demanded changes to the Basic Law of the country - the Constitution of Ukraine, which was implemented by the Law of Ukraine dated June 2, 2016 No. 1401-VIII "On Amendments to the Constitution of Ukraine (on Justice)" 28 .

These legislative innovations are reformist and very ambitious, their effectiveness and real results (as well as shortcomings) can be fully manifested in the medium and long term. Experts of the judicial reform proceed from the fact that these are her first steps, which will require, on the one hand, a steady adherence to the laws already adopted, and on the other, the next steps to promote the reform through legislative means.

The main component of this stage of judicial reform, provided for by these laws, is the creation of a new judicial system for Ukraine, including local courts, courts of appeal, and the Supreme Court of Ukraine. Such a system of justice is

\footnotetext{
${ }^{26}$ Відомості Верховної Ради України (ВВР), 1992, № 6, Ст. 56.

${ }^{27}$ Відомості Верховної Ради (ВВР). 2016. № 31. Ст. 545.

${ }^{28}$ Відомості Верховної Ради (ВВР), 2016, № 28, Ст. 532.
} 
intended (and, as the first results and opinions of experts already show, positive changes take place) to make the court open, transparent, accessible to the ordinary citizen. So, at present, any person online can get information about the composition of the court, the cases that are considered there, the decisions taken. The possibilities for citizens to attend court sessions, audio and photo fixing, video recording with a portable camera are also much democratized.

Very interesting from the standpoint of theoretical jurisprudence, is the legislative initiative to establish in the practice of Ukrainian justice the principle of the rule of law, designed to ensure the fairness of the decisions taken by the courts even in conditions of imperfection and inconsistency of the current legislation. This will be facilitated by the institution of a case (exemplary) case / This means that the decision made by the Supreme Court in a particular case will be an example (precedent) for other courts when considering other similar cases, which will prevent clearly illegal and unfair decisions, make decisions more open and predictable.

Or, for example, the new procedure for filling the posts of the Supreme Court, which until recently was closed, backstage, protectionist and corruption. Now, anyone who meets the formal requirements can take part in an open competition, and win - subject to successful passing of exams, tests, including psychological ones. Obviously, exam and test programs need to be improved in order to achieve $100 \%$ accuracy in the selection of applicants, but the existing practice of applying the new procedure indicates a move in the right direction.

Undoubtedly, the reform is not proceeding smoothly, citizens and society did not see rapid qualitative changes in the functioning of justice, even on the contrary, due to the dismissal of 2.5 thousand judges out of 8 thousand, the terms of consideration of cases increased, the efficiency of the courts decreased. We hope temporarily, otherwise people will be disappointed in this reform. In order to approve the meanings and tasks of judicial reform, new rules for re-evaluating judges, such new institutions as the High Council of Justice, the High Anti-Corruption Court and the High Court of Intellectual Property should be fully earned.

An important factor in improving the legal climate in the country is effective law enforcement. To this end, in Ukraine, one of the first, police reform was initiated (one of the reasons for the initiation of which was that the level of public confidence in the Ukrainian police at that time fell to 5\%). The fact that the situation has changed for the better, most experts say, is also considered by many citizens. According to the results of 2017, according to the Minister of Internal Affairs of Ukraine A. Avakov, the level of confidence in the new police is $40,7 \%{ }^{29}$. The lag in updating the police from the

29 URL: https://censor.net.ua/ua/news/3046947/riven_doviry_do_slujb_mvs_znachno_ vyris_avakov 
expectations of society is largely due to the inertia of the police system, the difficulties of recruiting new, modern police personnel (as the head of the National Police of Ukraine, Sergey Kniazev, admits, out of 132,000 police officers currently, only 18,000 are employed after 2015).

It should be recognized that the implementation of the reform of the law enforcement system is a very complex, responsible and sensitive process for the population. Therefore, there is first carried out the experimental implementation of innovations that are tested by national practice, and only after that they can be introduced throughout the country. So, now in the Kherson and Dnepropetrovsk regions an experiment is being conducted on the introduction of the custody records system, that is, the electronic registration system of the detainees, in which all actions concerning the detainee are recorded from the time it enters the temporary detention center. As you know, this is a British model, it works very effectively in its homeland, its strengths are that everything is controlled here, there are no moments when human rights violations are possible, because it fixes who performs certain actions. It is also recorded that the face is under video surveillance. The introduction of this practice requires significant financial resources for the acquisition of technical equipment and personnel training, but experts consider it very necessary.

The implementation of the service approach to its development is considered to be very promising in the transformation of the Ukrainian police. Some experts believe that the police should become a service. Service centers established in many regions that provide administrative services are already working in this direction. As Denis Monastyrsky, an expert of the program of reforming law enforcement and judicial systems, notes: “... for the second year the police have mastered the Scandinavian experience in working with mass meetings and meetings. I see a positive trend in the fact that we have a negotiating police; it is also called the "police of dialogue". In many large cities, they go to rallies, without weapons, even without uniform, communicate with the protesters, helping them to realize their right. And this is an element of the philosophy that the police should be a service ..."30.

Another important area of police reform in Ukraine is the evaluation of its activities by the level of public confidence. As envisaged by the Order of the Ministry of Internal Affairs of November 9, 2018 No. 900, registered by the Ministry of Justice of Ukraine on November 29, 2018 31 , an assessment of the level of public confidence in the National Police is carried out using indicators such as crime, police performance and police failures, as well as police and

30 Нова поліція і старі проблеми: що не так 3 правоохоронною реформою. URL: https://ukr.segodnya.ua/ukraine/novaya-policiya-i-starye-problemy-chto-ne-tak-s-pravoohranitelnoyreformoy-1161735.html

${ }^{31}$ URL: https://ips.ligazakon.net/document/view/RE32810?an=1 
public relations. The procedure for assessing the level of public confidence in the National Police is provided for by the Resolution of the Cabinet of Ministers of Ukraine of February 2, 2018 No. 58 "On Approving the Procedure for Assessing the Level of Public Confidence in the National Police of Ukraine" 32 . It seems that in this way the "feedback" of the police with the population, which is so necessary in law enforcement, will be strengthened, which should contribute to the improvement of its activities.

Important for foreign investors in such a large, on a European scale, country like Ukraine, are also regional conditions for doing business and supporting investment activities. Local state administrations (district, oblast) are empowered to develop programs for the socio-economic development of the respective territories, make proposals for the creation of free economic zones, facilitate the creation of enterprises with foreign investments, carry out investment management, including with the participation of foreign investors, submit for discussion relevant bodies of proposals for attracting foreign investment in the economic development of relevant administrative-territorial units. Also, local governments organize events aimed at promoting the investment attractiveness of the region.

\section{CONCLUSIONS}

Attraction of foreign investments into the economy is reasonably considered to be one of the most powerful resources for its development, so it is extremely important for Ukraine. The attractiveness of the country for foreign investment is determined by a number of factors, one of the most significant is modern, encouraging inward investment legislation, relevant law practice functioning of the economy and business, an adequate level of protection for business institutions of justice and law enforcement systems, tolerant attitude to business, including a foreign one. In this sense, it is a legal procedure in the area of investment and enterprise development that business is particularly sensitive concerning the country, the economy of which is planned to invest into.

Legal order is an integral indicator of the legal life quality of the state and society-legislation, its ability to protect rights and freedoms, property, economy, entrepreneurs, foreign investment among other things, against undue influence (crime, racketeering, corruption, arbitrary political decisions, populism), functioning of state institutions in strict accordance with the law, the effective functioning of the judicial system under the rule of law, as well as sustainable respect for law in society and its proper implementation by citizens, organizations and institutions.

\footnotetext{
${ }^{32}$ URL: https://ips.ligazakon.net/document/view/KP180058?an=1
} 


\section{SUMMARY}

In general, the material cited here shows that Ukraine, having embarked on the implementation of European business standards, consistently establishes them in national legislation, approves the practice of its precise and strict observance, and provides the necessary state guarantees. This creates positive conditions for strengthening the legal order in the sphere of economic activity and business, forming the image of Ukraine as an attractive country for foreign investment.

\section{REFERENCES}

1. Бачинин В.А. Философия права и преступления. Харьков: Фолио, 1999. $607 \mathrm{c}$.

2. Алексеев С.С. Право: азбука - теория - философия: Опыт комплексного исследования. М.: “Статут”, 1999. 710 с.

3. Кистяковский Б.А. Социальные науки и право. Очерки по методологии социальных наук и общей теории права. М., 1916. С. 336.

4. Нерсесянц В.С. Философия права. Учебник для вузов. М.:Издательская группа ИНФРА - М - НОРМА, 1997. 652 с.

5. Покровский И.А. Основные проблемы гражданского права. М.: Статут. 1998. 234 c.

6. Дражина И.В., Пономаренко Е.В. Правовое освоение действительности в системе юридических категорий. Тюмень, 1995. $144 \mathrm{c}$.

7. Фархутдинов И.З. Международное инвестиционное право и процесс. М.: Изд-во “Проспект”. 2010. 683 с.

8. Действующее международное право. Документы в 2-х томах. Т. 1. Составители Ю.М. Колосов, Э.С. Кривчикова. М.: Междун. отношения. 2002. $768 \mathrm{c}$.

9. Конвенція про порядок вирішення інвестиційних спорів між державами та іноземними особами. URL: https://zakon.rada.gov.ua/ laws/show/995_060

10. Сеульська конвенція 1985 р. про заснування багатостороннього агентства 3 гарантій інвестицій. URL: https://zakon.rada.gov.ua/ laws/show/995_268

11. Угода про пов'язані 3 торгівлею інвестиційні заходи. URL: https://zakon5.rada.gov.ua/laws/show/981_009/

12. Про інвестиційну діяльність: Закон України від 18 вересня 1991 p. № 1560-XII. Відомості Верховної Ради України. 1991, N 47, ст. 646.

13. Про режим іноземного інвестування: Закон України від 19 березня 1996 р. № 93/96-ВР. Відомості Верховної Ради Украӥни. 1996, N 19, ст. 80 . 
14. Про захист іноземних інвестицій в Україні: Закон України від 10 вересня 1991 р. № 1540а-XII. Відомості Верховної Ради України. 1991, N 46, ст. 616.

15.Про усунення дискримінації в оподаткуванні суб'єктів господарювання, створених 3 використанням майна та коштів вітчизняного походження: Закон України від 17 лютого 2000 p. Відомості Верховної Ради України. 2000, № 12, ст. 97.

16. Господарський Кодекс України. Відомості Верховної Ради Украӥни. 2003, № 18, № 19-20, № 21-22, ст. 144.

17. Курпаяниди К.И. Актуальные вопросы оценки инвестиционной привлекательности и факторы активизации инвестиционных потоков. Экономика, предпринимательство и право. 2011. № 9. С. 11-18.

18. Про внесення змін до деяких законодавчих актів України щодо спрощення ведення бізнесу та залучення інвестицій емітентами цінних паперів: Закон України від 16 листопада 2017 р. № 2210-VIII. Вiдомості Верховної Ради. 2018. № 6-7, ст. 38.

19. Про внесення змін до деяких законодавчих актів України щодо захисту прав інвесторів: Закон України від 7 квітня 2015 р. № 289-VIII. Відомості Верховної Ради. 2015, № 25, ст. 188.

20. Господарський процесуальний кодекс України. Вiдомості Верховної Ради України. 1992. № 6. ст. 56.

21. Про судоустрій і статус суддів: Закон України від 2 червня 2016 р. № 1402-VIII. Відомості Верховної Ради. 2016. № 31, ст. 545.

22. Про внесення змін до Конституції України (щодо правосуддя): Закон України від 2 лютого 2016 р. № 1401-VIII. Відомості Верховної Ради. 2016. № 28, ст. 532.

23. Уровень доверия к службам МВД значительно вырос. URL: https://censor.net.ua/ua/news/3046947/riven_doviry_do_slujb_mvs_znachno_ vyris_avakov.

24. Нова поліція і старі проблеми: що не так 3 правоохоронною реформою. URL: https://ukr.segodnya.ua/ukraine/novaya-policiya-i-staryeproblemy-chto-ne-tak-spravoohranitelnoyreformoy1161735.html.

Information about the author:

Kryzhanovskii A. F., Doctor of Legal Sciences, Professor, Head of State Law Disciplines Department, International Humanities University 33, Fontanska Road str., Odessa, 65009, Ukraine 